\title{
Parikarthika: The Most Misinterpreted Disease of Present Times
}

\author{
Review Article
}

\section{Yarlagadda Narendra Kumar ${ }^{1}$, Anumarlapudi Jayaram ${ }^{2 *}$}

1. Professor, 2. Professor, Department of P.G.Studies of Shalya Tantra, L.K.R. Ayurveda Mahavidyalaya, Gadhinglaj, Dist.Kolahapur, Maharashtra.

\begin{abstract}
In the present day of interdisciplinary references, investigations and patient consultations, it is necessary that any modern equivalent term should depict the exact disease our Acharyas meant it to be, so that all the Ayurvedic practitioners understand the same disease while referring to a modern term and the principles followed accordingly. Unfortunately some diseases are misinterpreted and the treatment followed is not as per Ayurvedic texts but what the modern term means. One such disease is Parikarthika, which is represented as fissure-in-ano but in fact is Proctitis. Here an attempt is made to restrict its use strictly to the disease our Acharyas mentioned and to follow the principles accordingly, for successful propagation of the system.
\end{abstract}

Keywords: Parikarthika, Gudakshatha, Pichchavasthi, Herbal enemata, Proctitis, Fissure-in-ano.

\section{Introduction}

Parikarthika, explained in both Charaka and Sushrutha Samhithas, is correlated to Fissure-in-ano commonly and authenticated by CCIM by giving it as equivalent in the syllabus papers of undergraduate course. When we study the explanation given by them in the texts, it will be evident that the disease they explained is not Fissure-in-ano but a different one. Explanation by both Charaka and Sushrutha mention mainly cutting type of pain in anal region and not a cut or lacerated wound/ulcer in the region. Even the treatment aspect advises to give Sneha vasthi which is contra-indicated in case of fissure, in fact even digital examination is not tolerated by the patient. If one studies the causes and signs and symptoms of Proctitis, one can note that those explained for Parikarthika match without an iota of doubt. Even the treatment aspect is same in both the systems for the above conditions of Parikarthika vis-à-vis Proctitis and Fissure-in-ano vis-à-vis Gudakshatha.

In the present day, due to wrong representation of the disease, the condition of Proctitis is completely forgotten and Gudakshatha treatment is given for Parikarthika considering it as fissure. Correction of this anomaly is of utmost importance, to properly diagnose these two different conditions and apply the principles of treatment properly.

Here we discuss the points substantiating the above statement.

\footnotetext{
*Corresponding Author:

Anumarlapudi Jayaram

Professor,

Department of PG Studies of Shalya Tantra,

L.K.R. Ayurveda Mahavidyalaya,

Gadhinglaj, Dist.Kolahapur, Maharashtra.

E-mail ID: anumarlapudi j@yahoo.co.in
}

\section{Aims}

To establish Parikarthika as Proctitis and Fissurein-ano as Gudakshata.

\section{Objectives}

- To peruse Parikarthika as mentioned in Ayurvedic classics

- To peruse Gudakshatha as mentioned in Ayurvedic classics

- To compare Proctitis and Fissure-in-ano with Parikarhtika and Gudakshatha respectively

- To clear ambiguity in the presentation and treatment of these diseases in Ayurveda

\section{The Relevant diseases \\ Parikarthika}

When potent medicines are administered orally to a person who is snigdha (unctuous) with Guru koshta, Ama dosha; emaciated, tired after strenuous physical errands, weakened; it enters the anal region causes doshas with Ama to be excreted with mucous and blood. Due to this the patient will experience pain as though cutting with scissors (1).

Charaka also states the disease as side effect of enema. In siddhi sthana chapter 7 - he says,

In a person of delicate digestive system, minimal doshas; if administered with rooksha and teekshna (dry and powerful) enema or if administered excessive than indicated dose, the doshas in the intestines are pushed out causing Parikarthika which exhibits the symptoms and signs as pain in the coccyx, inguinal region, pricking pain in the bladder and pain in the hypogastric region. Faeces gets dried up and expelled frequently in little quantity (2).

In the treatment he advises apart from other oral medicines, enema with decoction made from astringent or sweet cool drugs. He also recommends Pichchavasthi or Snehavasthi prepared with Liquorice apart from other drugs (3). 


\section{Sushrutha states}

"The Vayu and Pitta in the organism of an enfeebled person or of a person whose bowels can be easily moved or one of a dry and arid temperament or afflicted with impaired digestive capacity, are deranged and aggravated by the use of any extremely sharp, hot, saline or dry emetic or purgative which gives rise to a sort of cutting, sawing pain in the anus, penis, umbilical region and the neck of the bladde.

The remedy consists in employing a Pichchha Vasti with Yashtimadhu and black sesamum pasted together and dissolved in clarified butter and honey (4).

\section{Gudakshatha (Kshate Gudam)}

A displacement or retroversion of the pipe during the application of a Vasti produces a painful and bleeding ulcer in the rectum, which should be treated as a recent or incidental ulcer (5). An extremely up-turned or down-turned posture of the pipe at the time gives rise to a pain in the rectum which should be treated with Pitta subduing remedies and sprinkled with Sneha (oil, clarified butter) (6).

\section{Proctitis}

Herbal enema commonly in Tropical Africa consisting of Ginger, pepper and bark causes a virulent Proctitis (7).

Apart from other reasons like different infections and inflammatory diseases enema induced Proctitis, especially of herbal enemas are causes of Proctitis (8)

Clinical features are pain in rectal and anal areas, tenesmus with frequent bloody mucoid stools, pain and tenderness in the left lower abdomen (9).

\section{Discussion}

When we peruse the definition and explanation of Parikarthika, we notice that main stress was given to excessive use of enemata and drugs used to induce Virechana with highly potent medicines. This corroborates with modern clinical observation of herbal enemata induced Proctitis. The symptoms of Proctitis and Parikarthika are exactly same and no where they represent fissure-in-ano. Furthermore it will be a mistake and injustice to think that Sushrutha, father of surgery and practical anatomy has noted the symptom as cutting pain and not visualized the lacerated lesion in the anal area.

Treatment also consists of curative enemata as mentioned by Sushrutha and we know that any digital or instrumental investigation is not tolerated in fissure and is contraindicated let alone enema, while local suppositories are indicated depending on the causative factors in Proctitis.

Sushrutha mentions about Kshata guda or injury to the anal area due to improper instrumentation or broad speculum or enema tip as a cause and by inference even a hard stool causes the same effect and treatment principles are as of wound - suddha Vrana. The treatment adopted by the thesis workers and practitioners of Ayurveda is same and treated as incidental ulcers corroborating his view.

\section{Conclusion}

Parikarthika is the most misinterpreted disease of the present times. It is compared vis-à-vis fissure while the classical explanation doesn't mean it. It is obvious that while doing so, the main disease Parikarthika is neglected and fissure treatment is followed for a wrongly named disease. It is time that this disease is properly diagnosed with reference to the classical texts and treatment adopted for Proctitis to establish the treatment outcome (for Proctitis), while this is totally missed in the present treatment and teaching schedules.

We can note that the disease Parikarthika is wrongly compared to fissure-in-ano and treatment principles followed are for Gudakshatha, which actually is Fissure-in ano. Other way round Fissure-inano is diagnosed as Parikarthika and treated as per principles of Gudakshatha, while Proctitis is completely ignored. By studying the facts mentioned, it will only be proper to correlate Parikarthika with Proctitis and follow treatment principles of Parikarthika, when we diagnose in modern medicine, a case of Proctitis.

\section{References}

1. Priyavrath Sharma, Charaka Samhitha English Traslation, Volume II, Siddhi Sthana 6/61,62 Varanasi, Chowkamba Orientalis Publications, 2011, 629p

2. Priyavrath Sharma, Charaka Samhitha English Traslation, Volume II, Siddhi Sthana 7/54,55 Varanasi, Chowkamba Orientalis Publications, 2011, 637p

3. Priyavrath Sharma, Charaka Samhitha English Traslation, Volume II, Siddhi Sthana 6/67, Varanasi, Chowkamba Orientalis Publications, 2011, 629p

4. Kaviraj Kunjlal Bhishagratna, An English Translation of The Sushrutha Samhitha Volume II, Chikitsa Sthana XXXIV/16, Calcutta, Wilkins Press 1907, 586p

5. Kaviraj Kunjlal Bhishagratna, An English Translation of The Sushrutha Samhitha Volume II, Chikitsa Sthana XXXIV/2, Calcutta, Wilkins Press 1907, 600p

6. Kaviraj Kunjlal Bhishagratna, An English Translation of The Sushrutha Samhitha Volume II, Chikitsa Sthana XXXIV/2, Calcutta, Wilkins Press 1907, 600p

7. Norman S. Williams, Christopher J.K. Bulstrode \& P. Ronan O'Connel, Bailey \& Love's SHORT PRACTICE OF SURGEY, 26ed., New York, CRC Press, 2013, 1223p

8. Sriram Bhat M, SRB's Manual Of Surgery, 4th ed., New Delhi, Jaypee Brothers Medical Publishers (P) Ltd.,2013, 1060p.

9. Sriram Bhat, SRB's Clinical Methods in Surgery, $1^{\text {st }}$ ed.,New Delhi, Jaypee Brothers Medical Publishers (P) Ltd., 2010, 583p. 